\title{
External Quality Monitoring of the Cervical Cytopathological Exams in the Rio de Janeiro City
}

\section{Monitoramento externo da qualidade dos exames citopatológicos cervicais na cidade do Rio de Janeiro}

\author{
Vânia Stiepanowez de Oliveira Rocha ${ }^{1}$ Solange da Silva Malfacini ${ }^{1} \quad$ Alex Moreira Gomes $^{1}$ \\ Cláudia Ramos Marques da Rocha ${ }^{1}$ \\ ${ }^{1}$ Municipal Health Secretary of Rio de Janeiro, Rio de Janeiro, RJ, \\ Brazil \\ Address for correspondence Vânia Stiepanowez de Oliveira Rocha, \\ Secretaria Municipal de Saúde do Rio de Janeiro, Rua Afonso \\ Rev Bras Ginecol Obstet 2018;40:338-346. \\ Cavalcanti, 455, Rio de Janeiro, RJ, 20211-110, Brazil \\ (e-mail: vania.stiepanowez@uol.com.br).
}

\begin{abstract}
Keywords

- quality control

- cytodiagnosis

- uterine cervical neoplasms

- mass screening
\end{abstract}

Resumo
Objective To discuss the implementation and contributions of the External Quality Monitoring in the city of Rio de Janeiro and to analyze the performance of the main providers of cervical cytopathology in this city from September 2013 to March 2017, here referred to as "Alpha laboratory" and "Beta laboratory."

Methods Observational, cross-sectional, retrospective study using information from the Cervical Cancer Control Information System (SISCOLO, in the Portuguese acronym), municipal coordination module, External Quality Monitoring report. The proportions of false positives, false negatives, unsatisfactory samples and rejected samples were estimated. The agreement among the observers was analyzed through the Kappa index and the reduction of disagreements in the period for each laboratory studied, comparing the results of each cycle.

Results A total of 19,158 examinations were selected, of which 19,130 (99.85\%) were monitored, 16.649 (87, 03\%) were reviewed by the External Quality Monitoring Unit, $2,481(12,97 \%)$ were rejected and $441(2,65 \%)$ were considered unsatisfactory. The "Beta laboratory" presented excellent concordance in all cycles; the "Alpha laboratory" had good concordance in the first two cycles ( $K=0.76$ and 0.79 ), becoming excellent in the following four cycles. The average Kappa index was 0.85 , with median of 0.86 . The percentage of diagnostic disagreement was $6.63 \%$ of the reviewed exams, of which $5.38 \%$ required a change of conduct

Conclusion External Quality Monitoring is an exercise in diagnostic improvement, and its implementation was fundamental to ensure the reliability of the cytopathological exams in the city of Rio de Janeiro.

Objetivo Discutir a implementação e as contribuições do Monitoramento Externo da Qualidade na cidade do Rio de Janeiro e analisar o desempenho dos principais received

December 12, 2017

accepted

April 10, 2018

published online

June 20, 2018
DOI https://doi.org/

$10.1055 / \mathrm{s}-0038-1657755$ ISSN $0100-7203$.
Copyright $\odot 2018$ by Thieme Revinter

Publicações Ltda, Rio de Janeiro, Brazil
License terms

(c) (i) $\ominus$ (\$) 
provedores de citopatologia cervical nessa cidade no período de setembro de 2013 a março de 2017, aqui denominado "laboratório Alfa" "e" "laboratório Beta."

Métodos Estudo observacional, transversal, retrospectivo, utilizando informações do Sistema de Informação de Controle do Câncer do Colo do Útero (SISCOLO), do módulo de coordenação municipal, e do relatório de Monitoramento da Qualidade Externa. As proporções de falsos positivos, falsos negativos, amostras insatisfatórias e amostras rejeitadas foram estimadas. A concordância entre os observadores foi analisada através do índice Kappa bem como a redução de divergências no período para cada laboratório estudado, comparando os resultados de cada ciclo.

Resultados Foram selecionados 19.158 exames, dos quais 19.130 (99,85\%) foram monitorados, $16.649(87,03 \%)$ foram revisados pela Unidade de Monitoramento da Qualidade Externa, 2.481 (12,97\%) foram rejeitados e 441 (2,65\%) foram considerados insatisfatório. O "laboratório Beta" apresentou excelente concordância em todos os ciclos; o "laboratório Alfa" apresentou boa concordância nos 2 primeiros ciclos

\section{Palavras-chave}

- controle de qualidade

- citodiagnóstico

- neoplasias do colo do útero

- triagem em massa
$(K=0,76$ e 0,79$)$, tornando-se excelente nos 4 ciclos seguintes. $O$ índice Kappa médio foi de 0,85 , com mediana de 0,86 . O percentual de discordância diagnóstica foi de $6,63 \%$ dos exames revisados, dos quais 5,38\% necessitaram de mudança de conduta. Conclusão O Monitoramento Externo da Qualidade é um exercício de aprimoramento diagnóstico, e sua implementação foi fundamental para garantir a confiabilidade dos exames citopatológicos no município do Rio de Janeiro.

\section{Introduction}

With $\sim 530,000$ new cases per year worldwide, cervical cancer is the fourth most common form of cancer among women, accounting for the deaths of 266,000 women per year. ${ }^{1}$ In Brazil, it is the third most frequent type of cancer, with an adjusted mortality rate for the world population of 4.98 per 100 thousand women in $2015 .^{2}$ A total of 16,370 new cases are estimated for the $2018 / 2019$ period, 490 in the Rio de Janeiro city. $^{3}$

It is possible to reduce the incidence and mortality due to cervical cancer with early detection through screening, diagnostic confirmation and treatment of precursor lesions in a timely manner. The strategy used in Brazil for its screening is cytopathologic examination of the uterine cervix in women aged 25 to 64 years, with intervals of 3 years, after 2 negative annual tests.

The specific clinical course to be adopted based on the results of these tests is based on the Brazilian Nomenclature for Cervical Cytopathological Reports ${ }^{4}$ and must follow the recommendations of the Brazilian Guidelines for the Screening of Cervical Cancer, reviewed in 2016. ${ }^{5}$

With the development of the Cervical Cancer Control Information System (SISCOLO, in the Portuguese acronym) in 1999, in a partnership between the National Cancer Institute José Alencar Gomes da Silva (INCA, in the Portuguese acronym) and the Information Technology Department of the Unified National Health System (DATASUS, in the Portuguese acronym), it became possible to manage and monitor cervical cancer control actions throughout the country. The SISCOLO allows the preparation of reports, among them the External Quality Monitoring (MEQ in the Portuguese acronym). ${ }^{6}$
Through the analysis of the MEQ it was observed that most of the Brazilian laboratories present quality indicators of the cervical cytopathological exam outside the recommended standards. ${ }^{7,8}$ This test presents a variable sensitivity, mainly due to the subjectivity of the analysis, which can cause intra- and interobserver errors. As a strategy to ensure the continuous improvement of the quality of cervical cytopathology, the Ministry of Health proposed the implementation of MEQ which consists of a review of the cytopathological exams by a laboratory other than the one that performed the first reading. ${ }^{9,10}$

In Brazil, the concern with the quality of these examinations was made official with ministerial order $\mathrm{n}^{\circ} .79$, of July $6,1998,{ }^{11}$ joint ministerial order $\mathrm{N}^{\circ}$. 92, of $2001,{ }^{12}$ the National Program for the Control of Cervical and Breast Cancer, launched on March 22, 2011 ${ }^{13}$ and the Federal decree $n^{\circ} .3,388$ of December 30, 2013. ${ }^{14}$

The MEQ in Municipality of Rio de Janeiro (MRJ, in the Portuguese acronym) was implemented in 2013 following the recommendations made by INCA. The flow was agreed between representatives of the Primary Care Superintendency, the Cancer Technical Area Management (GCA, in the Portuguese acronym).) and the External Quality Monitoring Unit (UMEQ in the Portuguese acronym), with adaptations over the years for the needs identified posteriorly.

At each cycle, between the fifth and tenth working days of the current month, the municipal coordination sends the "External Quality Monitoring File" and the "list of exams to be reviewed" to the UMEQ and the "list of exams to be reviewed" to the monitored laboratory.

The monitored laboratory delivers the slides listed to the UMEQ within 10 days (from the receipt of the list), and the 
slides are packed in appropriate and labeled transport boxes, organized in ascending numerical order and in correspondence with the copies of the reports. The carton must be completely filled, void spaces are filled with bubble wrap or similar so there is no loss of sequence during transport.

The UMEQ reviews the exams within 30 calendar days (preanalytical, analytical and postanalytical phases), which can be extended to 45 days if there are more than 2,500 exams to be reviewed, considering the technical limit of 2,500/month established by it. At the end of the review, the UMEQ returns all the slides with identification of the discordant ones (clinically relevant) accompanied by the reports of the MEQ.

If there is interest of the monitored laboratory, because it does not comply with the UMEQ report, a consensus meeting must be held for joint analysis of the discordant cases, to be scheduled by the monitored laboratory, sending to the UMEQ an Excel listing and the slides to be analyzed within 5 working days prior to the meeting.

Once the definitive reports have been released, the UMEQ prepares the final report and generates the files "Exports and Outpatient Production Report (BPA, in the Portuguese acronym) of the MEQ," closing the corresponding competence, and sends them to the Municipal Health Secretariat of Rio de Janeiro (SMS-RJ, in the Portuguese acronym).

The municipal coordination evaluates the new reports and sends them to the General Coordinators of Primary Care of the Planning Areas (CAPs, in the Portuguese acronym), assigning to the Primary Health Care Units (APS, in the Portuguese acronym), for active search, a list of women with an indication to repeat cytopathological exam or colposcopy, according to the MEQ result. This list is accompanied by a personalized invitation letter, prepared by the Technical Area of Cancer Management, in agreement with the UMEQ and the monitored laboratories, clarifying to the women about the quality control process and requesting their attendance at the APS to perform a new exam of control or be scheduled to the secondary reference unit. In cases of repetition of the exam, the GCA send to the units the definitive results to be registered, informed and delivered after counseling with an attending professional.

Three units of secondary referral in cervical pathology in the city of Rio de Janeiro participated in the process welcoming women with a change of diagnosis after MEQ for diagnostic investigation, with a schedule made by the management of the cancer technical area. Until 2016, this schedule was made by e-mail, being included in the Regulation Center System (SISREG, in the Portuguese acronym) in 2017. Parallel to the scheduling, the GCA sends to the secondary unit the nominal listing, results (original and MEQ) and guidelines regarding the reception of these women.

From September 2013 to March 2017, it was possible to improve the External Quality Monitoring, increase the number of cycles, strengthen the partnerships involved in the process, evaluate the performance in the cervical cytopathology diagnosis of the two main laboratories contracted that provide this service to the public primary health care units in the city of Rio de Janeiro, discuss the difficulties in the process and their contributions to the quality line of cervical cancer care.
The objective of this study was to present the experience of the city of Rio de Janeiro in the performance of the MEQ from September 2013 to March 2017, and the performance of the participating laboratories, analyzing the interobserver agreement, proportions of unsatisfactory exams, rejected samples, false-negative and false-positive tests over time.

\section{Methods}

A descriptive, observational, cross-sectional, retrospective study was performed using information from the SISCOLO, municipal coordination module of Rio de Janeiro, MEQ report of the cervical samples evaluated by the two main laboratories that provide this service to the public primary health care network in the city of Rio de Janeiro and the exams reviewed by the UMEQ.

The sample consisted of 16,649 records of cervical cytopathological examinations performed by the participating laboratories, reviewed in the MEQ, from September 2013 to March 2017, including all the exams entered in SISCOLO in this period. Those inserted in the period after March 2017 and those that were not included in this database were excluded.

The data was collected from the synthetic reports of each MEQ using aggregate records of the results of the monitored laboratory and review.

The cytopathological examinations of the cervix were considered as rejected when they were outside the minimum criteria necessary for the UMEQ review; unsatisfactory when reading was impaired by the presence of acellular or hypocellular material ( $<10 \%$ of the smear); when there was presence of blood, pyocytes, drying artifacts, external contaminants or intense cellular superposition, not allowing a diagnostic conclusion normal; ${ }^{9-15}$ when results were within the limit of normality; when there was inflammation, benign cellular alterations and when they were positive according to the Brazilian Nomenclature for Cytopathological Reports. ${ }^{9}$

Discordant exams, with a change of diagnostic category implying a change in clinical behavior after the execution of the MEQ, were classified as: false negatives, those whose monitored laboratory classified as normal or benign alteration, and after the review, the result was atypical squamous cells of unknown significance (ASC-US), low-grade squamous intraepithelial lesion (LSIL), atypical squamous cells, cannot rule out high-grade squamous intra-epithelial lesion (ASC$\mathrm{H}$ ), more severe or unsatisfactory results and false-positive results when the monitored laboratory defined the outcome as ASC-US, LSIL, ASC-H or more severe outcomes and, after review, the report was unsatisfactory, normal, or benign. Cases with change in diagnosis without causing change in clinical behavior were also considered discordant.

For the analysis of agreement among the observers, based on each MEQ performed, the Kappa (K) index was used. The statistical method Kappa is divided into six categories, according to - Table 1.

The proportions of false positives, false negatives, unsatisfactory samples and rejected samples were estimated, as well as the reduction of disagreements for each laboratory. 
Table 1 Kappa (K) interpretation

\begin{tabular}{|l|l|}
\hline \multicolumn{2}{|l|}{ Kappa interpretation } \\
\hline $\mathrm{K}=1$ & Perfect agreement \\
\hline $0.80<\mathrm{K}<1$ & Excellent agreement \\
\hline $0.60<\mathrm{K}<0.80$ & Good agreement \\
\hline $0,40<\mathrm{K}<0.60$ & Moderate agreement \\
\hline $0<\mathrm{K}<0.40$ & Poor agreement \\
\hline $\mathrm{K}=0$ & No agreement \\
\hline
\end{tabular}

Source: Landis and Koch (1977). ${ }^{16}$

After the collection and analysis of the records of the SISCOLO Synthetic Quality External Monitoring Reports, the information was tabulated in a Microsoft Excel (Microsoft Corp., Redmond, WA, USA) spreadsheet.

All information extracted from the system was analyzed and considered in secrecy, maintaining their anonymity, in order not to entail risks and damages to the participants. The project was approved by the Research Ethics Committee of the Municipal Health Secretariat of Rio de Janeiro on 08/29/ 2017-CAAE 70812117.6.0000.5279.

\section{Results}

Between September 2013 and March 2017, 12 cycles of MEQ of cervical cytopathology were performed in the city of Rio de Janeiro, with the participation of the two main laboratories contracted, here called "Alpha laboratory" and "Beta laboratory," with six cycles each.

A total of 19,158 exams were selected by SISCOLO, of which 19,130 (99.85\%) were monitored, 16,649 (87.03\%) were reviewed by the UMEQ, 2,481 (12.97\%) were rejected and 441 (2.65\%) were considered unsatisfactory (-Table 2).

The concordance between observers (monitored laboratory and reviewer) was evaluated using the statistical method Kappa (K), with a mean of 0.85 and median of 0.86 showing excellent agreement. The "Beta laboratory" presented excellent agreement in all MEQs, with Kappa ranging from 0.85 to 0.89 . The "Alpha laboratory" presented good agreement (Kappa from 0.76-0.78) in 2 cycles of the 2015 MEQ becoming excellent in the last cycle of the $2015 \mathrm{MEQ}$ 2016 and 2017, with Kappa varying from 0.81 to 0.92 (-Table 3). Of the 16,650 examinations reviewed, there was concordance in 15,546 (93.40\%), and disagreement in $1,104(6.63 \%)$, of which $895(5.38 \%)$ indicated a change of conduct ( - Table 3 ).

Of the 441 (2.65\%) unsatisfactory results, the UMEQ diagnosed $11(0.06 \%)$ atypical epithelial changes (2.5\%), 5 $(0.00 \%)$ in the "Beta laboratory" and $6(0.00 \%)$ in the "Alpha laboratory" (-Figs. 1 and $\mathbf{2}$ ).

The highest percentage of agreement between observers in the 2 monitored laboratories was observed between the normal results and benign alterations-7,438 (92.54\%) in the "Beta laboratory, 3,146 (86.64\%) in the" Alpha laboratoryand the highest diagnostic disagreement occurred in the results of atypical glandular cells (AGC), 164 (61.88\%) and 21 (43.75\%), respectively (-Figs. 1 and $\mathbf{2}$ ).

In 4 out of $8(50 \%)$ invasive carcinoma results, the "Beta laboratory" was in disagreement with the UMEQ regarding the results of 2 high-grade squamous intraepithelial lesion (HSIL) and 2 HSIL/HSIL microinvasion without change of care conduct. In the "Alpha Laboratory" there was $100 \%$ agreement (-Figs. 1 and $\mathbf{2}$ ).

Table 2 Records of the external reports of Quality External Monitoring (SISCOLO) with selected results, monitored results, revised results, unsatisfactory results, rejected samples and their percentages, by laboratory and monitoring cycle

\begin{tabular}{|l|l|l|l|l|l|}
\hline Laboratory Monitoring cycle & $\begin{array}{l}\text { SRs } \\
\mathbf{n}\end{array}$ & $\begin{array}{l}\text { MRs } \\
\mathbf{n}(\%)\end{array}$ & $\begin{array}{l}\text { RRs } \\
\mathbf{n}(\%)\end{array}$ & $\begin{array}{l}\text { URs } \\
\mathbf{n}(\%)\end{array}$ & RSs $\mathbf{n}(\%)$ \\
\hline BETA laboratory 092013 & 1,933 & $1,930(99.84)$ & $1,632(84.56)$ & $44(2.70)$ & $298(15.44)$ \\
\hline BETA laboratory 042014 & 771 & $768(99.61)$ & $738(96.09)$ & $42(5.69)$ & $30(3.91)$ \\
\hline BETA laboratory 122014 & 3,339 & $3,333(99.82)$ & $1,421(42.63)$ & $34(2.39)$ & $1,912(57.37)$ \\
\hline BETA laboratory 102015 & 2,041 & $2,041(100.00)$ & $1,996(97.80)$ & $20(1.00)$ & $45(2.20)$ \\
\hline BETA laboratory 012016 & 4,007 & $4,005(99.95)$ & $3,886(97.03)$ & $75(1.93)$ & $119(2.97)$ \\
\hline BETA laboratory 032017 & 1,796 & $1,795(99.94)$ & $1,773(98.77)$ & $23(1.30)$ & $22(1.23)$ \\
\hline ALPHA laboratory 012015 & 433 & $433(100.00)$ & $427(98.61)$ & $9(2.11)$ & $6(1.39)$ \\
\hline ALPHA laboratory 042015 & 1,201 & $1,200(99.92)$ & $1,170(97.50)$ & $29(2.48)$ & $30(2.50)$ \\
\hline ALPHA laboratory 092015 & 1,168 & $1,168(100.00)$ & $1,154(98.72)$ & $24(2.08)$ & $15(1.28)$ \\
\hline ALPHA laboratory 012016 & 546 & $546(100.00)$ & $544(99.63)$ & $7(1.29)$ & $2(0.37)$ \\
\hline ALPHA laboratory 052016 & 1,208 & $1,197(99.09)$ & $1,195(99.83)$ & $17(1.42)$ & $2(0.17)$ \\
\hline ALPHA laboratory 012017 & 715 & $714(99.86)$ & $714(100.00)$ & $20(2.80)$ & $0(0.00)$ \\
\hline Total & 19,158 & $19,130(99.85)$ & $16,650(87.03)$ & $344(2.07)$ & $2,481(12.97)$ \\
\hline
\end{tabular}

Abbreviations: MRs, monitored results; RSs, rejected samples; RRs, revised results; SISCOLO, Cervical Cancer Control Information System (in the Portuguese acronym); SRs, selected results; URs, unsatisfactory results. 
Table 3 Concordance in the results of cervical cytopathological examinations and disagreement with change of conduct by laboratory and monitoring cycle

\begin{tabular}{|c|c|c|c|c|c|}
\hline Laboratory monitoring cycle & Concordant n (\%) & Discordant n (\%) & $\begin{array}{l}\text { Discordant with } \\
\text { change of conduct } \\
n(\%)\end{array}$ & Total & Kappa \\
\hline BETA laboratory 092013 & $1,551(95.04)$ & $81(4.96)$ & $74(4.53)$ & 1,632 & 0.88 \\
\hline BETA laboratory 042014 & $682(92.41)$ & $56(7.59)$ & $39(5.28)$ & 738 & 0.85 \\
\hline BETA laboratory 122014 & $1,327(93.38)$ & $94(6.62)$ & $73(5.14)$ & 1,421 & 0.84 \\
\hline BETA laboratory 102015 & $1,863(93.34)$ & $133(6.66)$ & $106(5.41)$ & 1,996 & 0.87 \\
\hline BETA laboratory 012016 & $3,666(94.34)$ & $220(5.66)$ & $180(4.63)$ & 3,886 & 0.87 \\
\hline BETA laboratory 032017 & $1,681(94.81)$ & $92(5.19)$ & $83(4.68)$ & 1,773 & 0.88 \\
\hline ALPHA laboratory 012015 & $367(85.95)$ & $60(14.05)$ & $46(10.77)$ & 427 & 0.76 \\
\hline ALPHA laboratory 042015 & $1,050(89.74)$ & $120(10.26)$ & $93(7.95)$ & 1,170 & 0.79 \\
\hline ALPHA laboratory 092015 & $1,086(94.11)$ & $68(5.89)$ & $56(4.85)$ & 1,154 & 0.88 \\
\hline ALPHA laboratory 012016 & $503(92.46)$ & $41(7.54)$ & $31(5.70)$ & 544 & 0.82 \\
\hline ALPHA laboratory 052016 & $1,083(90.63)$ & $112(9.3)$ & $89(7.45)$ & 1,195 & 0.81 \\
\hline ALPHA laboratory 012017 & $687(96.22)$ & $27(3.78)$ & $23(3.22)$ & 714 & 0.92 \\
\hline Total & $15,546(93.40)$ & $1,104(6.63)$ & $895(5.38)$ & 16,650 & 0.85 \\
\hline
\end{tabular}

\begin{tabular}{|c|c|c|c|c|c|c|c|c|c|c|c|c|c|c|c|c|c|c|c|}
\hline Review Laboratory & 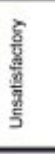 & $\begin{array}{l}\overline{\bar{\pi}} \\
\frac{\mathrm{g}}{2}\end{array}$ & 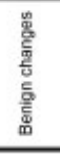 & 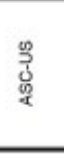 & $\underset{\frac{5}{5}}{\frac{\pi}{6}}$ & क् & 咅 & 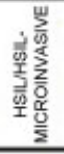 & 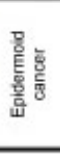 & 超 & ঠ্ৰ & $\frac{D}{4}$ & 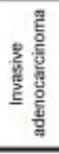 & 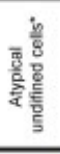 & 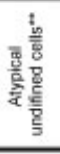 & 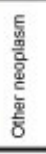 & 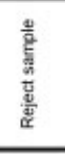 & 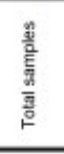 & 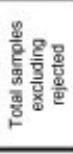 \\
\hline Unsatisfatory & 227 & 2 & 28 & 4 & 0 & 0 & 0 & 0 & 0 & 1 & 0 & 0 & 0 & 0 & 0 & 0 & 51 & 313 & 262 \\
\hline Normal & 0 & 38 & 290 & 3 & 1 & 0 & 0 & 0 & 0 & 0 & 0 & 0 & 2 & 0 & 0 & 0 & s6 & 390 & 334 \\
\hline Benign changes & 11 & 94 & 7400 & 126 & 10 & 45 & 7 & 0 & 0 & 8 & 1 & 0 & 1 & 0 & - & 0 & 1627 & 9330 & $n 03$ \\
\hline ASC-US & 0 & 0 & 123 & $11 a 8$ & 74 & 260 & 17 & 0 & 0 & 15 & 2 & 0 & 0 & 0 & 4 & 0 & 358 & 2041 & 1683 \\
\hline ASC-H & 0 & 0 & 3 & 17 & 175 & 4 & 82 & 3 & 0 & 2 & 2 & 0 & 1 & 0 & 0 & 0 & 63 & 352 & 289 \\
\hline LSIL & 0 & 0 & 7 & 33 & 10 & 572 & 52 & 1 & 0 & 0 & 0 & 0 & 0 & 0 & 0 & 0 & 142 & 817 & 675 \\
\hline HSIL & 0 & 0 & 3 & 0 & 13 & 5 & 174 & 4 & 1 & 1 & 0 & 0 & 0 & 0 & 0 & 0 & 41 & 242 & 201 \\
\hline HSIL/HSIL-microinvasive & 0 & 0 & 0 & 1 & 1 & 0 & 9 & 14 & 0 & 0 & 0 & 0 & 0 & 0 & 0 & 0 & 10 & 35 & 25 \\
\hline Epidemoid cancer & 0 & 0 & 0 & 0 & 0 & 0 & 2 & 2 & 4 & 0 & 0 & 0 & 0 & 0 & 0 & 0 & 3 & 11 & 8 \\
\hline AGC-US & 0 & 0 & 24 & 59 & 11 & 3 & 4 & 0 & 0 & 89 & 6 & 1 & 0 & 1 & 8 & 0 & 68 & 274 & 206 \\
\hline$A G C-H$ & 0 & 0 & 2 & 0 & 15 & 0 & 12 & 2 & 0 & 4 & 12 & 9 & 0 & 0 & 3 & 0 & 7 & 66 & 59 \\
\hline AIS & 0 & 0 & 0 & 0 & 0 & 0 & 0 & 0 & 0 & 0 & 0 & 1 & 0 & 0 & 0 & 0 & 0 & 1 & 1 \\
\hline Invasive adenocarcinoma & 0 & 0 & 0 & 0 & 0 & 0 & 0 & 0 & 0 & 0 & 0 & 0 & 0 & 0 & 0 & 0 & 0 & 0 & 0 \\
\hline Atypical undifined cells" & 0 & 0 & 0 & 0 & 0 & 0 & 0 & 0 & 0 & 0 & 0 & 0 & 0 & 0 & 0 & 0 & 0 & 0 & 0 \\
\hline Atypical undifined cells"* & 0 & 0 & 0 & 0 & 0 & 0 & 0 & 0 & 0 & 0 & 0 & 0 & 0 & 0 & 0 & 0 & 0 & 0 & 0 \\
\hline Other neoplasms & 0 & 0 & 0 & 0 & 0 & 0 & 0 & - & 0 & 0 & 0 & 0 & 0 & 0 & 0 & 0 & 0 & 0 & 0 \\
\hline Total & $23 b$ & 134 & 7880 & 1431 & 310 & 889 & 359 & 26 & 5 & 120 & 23 & $n$ & 4 & 1 & 15 & 0 & 2426 & 13872 & 11446 \\
\hline
\end{tabular}

Fig. 1 Synthetic external monitoring report produced by the cervical cancer information system (SISCOLO). Distribution of cytopathological results diagnosed by the review laboratory and the monitored laboratory (Beta), from September 2013 to March 2017.

Abbreviations: ASC-US, atypical squamos cells of undetermined significance not possible High grade lesion, ASC-H: atypical squamos cells of undetermined significance cannot exclude High grade lesion, LSIL: low grade squamous intrapithelial lesions, HSIL: High grade squamous intrapithelial lesions, HSIL/HSIL-microinvasor: High grade squamous intrapithelial lesions with suspeccious of microinvasion, AGC-US, atypical glandular cells of undetermined significance; AGC-H, atypical glandular cells cannot exclude high-grade glandular lesion; AIS, endocervical adenocarcinoma in situ; Al, adenocarcinoma invasor. *atypical undifined cells of undeterminated significance not possible high grade lesion; **atypical undifined cells of undeterminated significance cannot exclude high grade. 


\begin{tabular}{|c|c|c|c|c|c|c|c|c|c|c|c|c|c|c|c|c|c|c|c|}
\hline Review Laboratory & 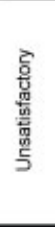 & 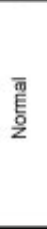 & 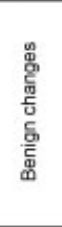 & 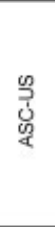 & $\begin{array}{l}\text { I } \\
\text { d } \\
\text { \& }\end{array}$ & ज़ & 롶 & 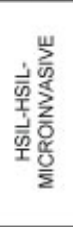 & 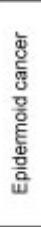 & 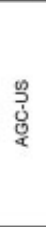 & $\begin{array}{l}T \\
\text { J } \\
0 \\
\text { \& }\end{array}$ & $\frac{\infty}{2}$ & 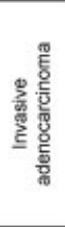 & 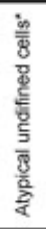 & 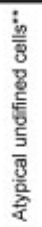 & 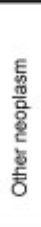 & 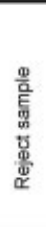 & 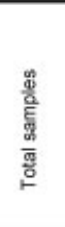 & 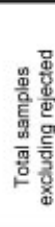 \\
\hline Unsatisfatory & 104 & 0 & 69 & 3 & 1 & 1 & 1 & 0 & 0 & 0 & 0 & 0 & 0 & 0 & 0 & 0 & 1 & 180 & 179 \\
\hline Normal & 0 & 8 & 30 & 0 & 0 & 1 & 0 & 0 & 0 & 0 & 0 & 0 & 0 & 0 & 0 & 0 & 0 & 39 & 39 \\
\hline Benign changes & 2 & 29 & 3138 & 33 & 11 & 20 & 5 & 0 & 0 & 2 & 0 & 0 & 0 & 0 & 0 & 0 & 10 & 3250 & 3240 \\
\hline Asc.us & 0 & 1 & 159 & 854 & 28 & 127 & 14 & 0 & 0 & 13 & 0 & 0 & 0 & 0 & 0 & 0 & 5 & 1201 & 1196 \\
\hline ASC-H & 0 & 0 & 7 & 12 & 97 & 2 & 42 & 0 & 0 & 2 & 0 & 0 & 1 & 0 & 1 & 0 & 1 & 165 & 164 \\
\hline LSIL & 0 & 0 & 1 & 21 & 7 & 213 & 16 & 0 & 0 & 1 & 0 & 0 & 0 & 0 & 0 & 0 & 1 & 260 & 259 \\
\hline HSIL & 0 & 0 & 0 & 0 & 9 & 0 & 60 & 3 & 0 & 0 & 0 & 0 & 0 & 0 & 0 & 0 & 1 & 73 & 72 \\
\hline HSILMSIL-microinvasive & 0 & 0 & 0 & 0 & 0 & 0 & 1 & 4 & 0 & 0 & 0 & 0 & 0 & 0 & 0 & 0 & 0 & 5 & 5 \\
\hline Epidermoid cancer & 0 & 0 & 0 & 0 & 0 & 0 & 0 & 0 & 1 & 0 & 0 & 0 & 0 & 0 & 0 & 0 & 0 & 1 & 1 \\
\hline AGC-US & 0 & 0 & 11 & 6 & 0 & 0 & 0 & 0 & 0 & 24 & 1 & 0 & 0 & 0 & 1 & 0 & 0 & 43 & 43 \\
\hline$A G C-H$ & 0 & 0 & 0 & 0 & 1 & 0 & 1 & 0 & 0 & 0 & 3 & 0 & 0 & 0 & 0 & 0 & 0 & 5 & 5 \\
\hline AIS & 0 & 0 & 0 & 0 & 0 & 0 & 0 & 0 & 0 & 0 & 0 & 0 & 0 & 0 & 0 & 0 & 0 & 0 & 0 \\
\hline Invasive adenocarcinoma & 0 & 0 & 0 & 0 & 0 & 0 & 0 & 0 & 0 & 0 & 0 & 0 & 0 & 0 & 0 & 0 & 0 & 0 & 0 \\
\hline Atypical undifined cells* & 0 & 0 & 0 & 0 & 0 & 0 & 0 & 0 & 0 & 0 & 0 & 0 & 0 & 0 & 0 & 0 & 0 & 0 & 0 \\
\hline Atypical undifined cells"* & 0 & 0 & 0 & 0 & 0 & 0 & 0 & 0 & 0 & 0 & 0 & 0 & 0 & 0 & 0 & 0 & 0 & 0 & 0 \\
\hline Other neoplasms & 0 & 0 & 0 & 0 & 0 & 0 & 0 & 0 & 0 & 0 & 0 & 0 & 1 & 0 & 0 & 0 & 0 & 1 & 1 \\
\hline Total & 106 & 38 & 3415 & 929 & 154 & 364 & 140 & 7 & 1 & 42 & 4 & 0 & 2 & 0 & 2 & 0 & 19 & 52223 & 5204 \\
\hline
\end{tabular}

Fig. 2 Synthetic external monitoring report produced by the cervical cancer information system (SISCOLO). Distribution of cytopathological results diagnosed by the review laboratory and the monitored laboratory (Alpha), January 2015 to January 2017.

Abbreviations: ASC-US, atypical squamos cells of undetermined significance not possible High grade lesion, ASC-H: atypical squamos cells of undetermined significance cannot exclude High grade lesion, LSIL: low grade squamous intrapithelial lesions, HSIL: High grade squamous intrapithelial lesions, HSIL/HSIL-microinvasor: High grade squamous intrapithelial lesions with suspeccious of microinvasion, AGC-US, atypical glandular cells of undetermined significance; AGC-H, atypical glandular cells cannot exclude high-grade glandular lesion; AIS, endocervical adenocarcinoma in situ; Al, adenocarcinoma invasor. *atypical undifined cells of undeterminated significance not possible high grade lesion; **atypical undifined cells of undeterminated significance cannot exclude high grade.

From the 1,683 (14.7\%) ASC-US results from the "Beta laboratory," the UMEQ diagnosed $17(0.14 \%)$ as HSIL, 17 (0.14\%) as AGC and 4 (0.03\%) as atypical undetermined cells; in $1,196(22.9 \%)$ ASC-US results of the "Alpha laboratory," the UMEQ diagnosed $14(0.02 \%)$ as HSIL and $13(0.02 \%)$ as AGC. In 675 (5.8\%) LSIL results from the "Beta laboratory," the UMEQ diagnosed $52(0.45 \%)$ as HSIL, $10(0.08 \%)$ as ASC-H and 1 $(0.00 \%)$ as HSIL/HSIL microinvasion; and in 259 (4.97\%) results of the "Alpha laboratory," the UMEQ diagnosed 16 $(0.30)$ as HSIL, $7(0.01 \%)$ as ASC-H and $1(0.00 \%)$ as AGC. In these cases, there was delay in the care delivery according to the established recommendations (-Figs. 1 and $\mathbf{2}$ ).

The 209 (1.83\%) false-negative results from the Beta laboratory were distributed in 133 (1.16\%) ASC-US, 45 (0.39\%) LSIL, 11 (0.10\%) ASC-H, 7 (0.06) HSIL, 10 (0.08\%) AGC and 3 (0.03\%) invasive adenocarcinoma, and in the "Alpha laboratory, there were $78(1.50 \%)$ false-negative results, with $36(0.69 \%)$ cases of ASC-US, 22 (0.42\%) LSIL, 12 (0.23\%) ASC-H, 6 (0.12\%) HSIL, 2 (0.04) AGC (- Figs. 1 and 2).
The $162(1.42 \%)$ false-positive results from the Beta laboratory were distributed in 123 (1.07\%) ASC-US, 3 (0.03\%) ASC H, 7 (0.06) LSIL, HSC and 26 (0.23\%) AGC, and in the "Alpha laboratory" were 178 (3.42\%) being 159 (3.06\%) ASC-US, 7 (0.13\%) ASC-H, 1 (0.02\%) LSIL, 6 (0.12\%) HSIL and 2 (0.04\%) AGC (-Figs. 1 and $\mathbf{2}$ ).

There was a change in clinical behavior in 895 (5.38\%) of the $1,104(6.63 \%)$ results with a discordant diagnosis from 2013 to 2017. In the "Beta laboratory" 555 (5.91\%) clinical conduct changes occurred in 676 (5.91\%) discordant results. Of these, 178 (1.56\%) were false-negative results that should have repeated cytology in 6 to 12 months; $31(0.27)$ were false-negative results that should have performed colposcopy; $162(1.42 \%)$ were false-positive results that required only the recommended screening and $11(0.10 \%)$ were negative reports given on unsatisfactory slides that should have been collected again in 6 to 12 weeks. In the "Alpha laboratory," there were 338 (6.50\%) changes in clinical behavior in the $428(8.22 \%)$ discordant results. Of these, 58 (1.11\%) were 
false-negative results that should have repeated the cytology in 6 to 12 months, $20(0.38 \%)$ were false-negative results that should have performed the colposcopy, 178 (1.42\%) were false positives that only needed the recommended screening and $2(0.10 \%)$ were negative reports given on unsatisfactory slides that should have been collected again in 6 to 12 weeks (-Figs. 1 and 2).

\section{Discussion}

The implementation of the MEQ of the cervical cytopathological exams in the city of Rio de Janeiro followed the recommendations from INCA, started in 2013. The participation of the laboratories was progressive, and the joint work was decisive to overcome the difficulties encountered. Since then, the MEQ has been performed systematically.

The diversity of methods used for the MEQ in other countries, the peculiarity of the model adopted in Brazil and the little literature on the subject make it difficult to compare with the results obtained by other authors.

The UMEQ evaluation process had three phases: preanalytical, analytical and postanalytical, which defined the examinations reviewed or rejected for nonconformities, unsatisfactory, false negatives and false positives. ${ }^{9}$

A total of 19,130 cervical cytopathological exams were monitored at the 2 participating laboratories, with rejection of 2,481exams (12.97\%), which were not reviewed by the External Quality Monitoring Unit (UMEQ) for presenting unconformities. Considering the whole sample, this indicator was well above the acceptable level $(0.1 \%),{ }^{9}$ and was strongly influenced by the performance of the "Beta laboratory," which showed rejection of 2,426 out of 13,872 monitored tests (17.49\%), and mainly in the third cycle, in which 1,912 out of 3,333 examinations were rejected (57.37\%). Educational interventions were performed, which resulted in a drop in the rejection percentage of this laboratory to $1.23 \%$ in the last cycle studied. This fact reinforces the importance of the actions of permanent education, quality assurance of the cervix cytopathological exam. The "Alpha laboratory" presented rejection of 55 out of 5,258 tests (1.05\%), not impacting the result of this indicator.

Of the 16,650 cervix cytopathological exams reviewed by the UMEQ in the period, 441 (2.65\%) were considered unsatisfactory, of which 239 / out of 11,446 (2,08\%) came from the "Beta laboratory," and 179 out of 5,203 (3.43\%) came from the "Alpha laboratory." This indicator remained within the acceptable limit (5\%), with the exception of only the third cycle of the "Beta laboratory" (5.69\%). In this regard, the results found in the present study were better than the results described in studies performed in Mato Grosso do Sul (11.4\%), Goiânia (21.0\%), and São Paulo (3.8\%) and were surpassed only by studies performed in Paraná (1.8\%). ${ }^{17-20}$ This data may reflect the good technical quality of the team performing the cervix cytopathological exams in the Municipal Units of Primary Health Care, the continuing education and effectiveness of the External, Internal Quality Monitoring program in improving the quality of these exams.
The performance of each participating laboratory was assessed based on the agreement between observers (Kappa index) and the discordant test percentage estimated in the MEQ cycles. It was observed that the concordance between observers (monitored laboratory/UMEQ) of the "Beta laboratory" remained excellent in all cycles of the studied period. In the "Alpha laboratory" the agreement was good in the first two cycles of MEQ becoming excellent in the following cycles. A progressive and significant improvement in agreement between the "Alpha laboratory" and UMEQ was observed over time.

In this study, the reviewers were aware of the initial report, which may have influenced the analyses. ${ }^{8,21}$ The report was made from the records of the External Synthetic Monitoring Report presenting the results of 16 categories of cytopathological diagnosis of the cervix. ${ }^{9}$

The median $\mathrm{K}$ index of the MEQ cycles in the city of Rio de Janeiro in this study was 0.86 , coming close to the $\mathrm{K}$ indexes of the states of Paraná $(0,88)^{20}$ São Paulo $(0.80),{ }^{19}$ corroborating the quality warranty of the reliability of cervix cytopathological exams performed by the laboratories evaluated. ${ }^{19,20}$

The percentage of diagnostic disagreement in the reviewed examinations was 6.63 , of which $5.38 \%$ required a change of conduct. Despite the low percentages, ${ }^{20}$ educational interventions are necessary because of their clinical impact. They were found predominantly in the results of squamous and glandular atypia of undetermined significance, in which the interobserver variability is greater, there is greater difficulty in defining the diagnosis, increasing the chance of false-negative and false-positive results. In the case of glandular atypia, the clinical implications are very relevant, as it requires a specific clinical management and it is related to more serious diseases. ${ }^{21}$

The delay in the care delivery according to the defined recommendations was observed in a small percentage in both laboratories $0.15 \%$.

The false-negative results of both laboratories predominated in the ASC-US category with low percentages, ${ }^{18,19}$ especially in cases of greater clinical relevance (postconsensus diagnosis of HSIL or more severe lesion), tending to decrease with cycles. These results have a great impact on screening programs, which may result in loss of follow-up, delaying the early diagnosis of precursor lesions of cervical cancer. ${ }^{10}$

The false-positive results presented their highest percentages in the ASC-US category, and although they were low, ${ }^{20}$ the "Beta laboratory" showed a tendency towards an increase in the incidence of false positives, while the "Alpha laboratory" showed a significant reduction. This reduction is important and necessary to avoid unnecessary diagnostic investigation, causing physical and emotional harm to women, undue occupation of places in specialized procedures, overloading and honoring health services. ${ }^{22}$

Diagnostic discordance leads to changes in clinical behavior that directly impact on quality of care and screening programs.

The results of false diagnoses are due to inadequate collection, technical failures in fixation, staining of the samples and errors in reading and interpretation of 
cytomorphological criteria, being more frequent in the border diagnosis, which involves greater subjectivity (ASC-US, ASC- H, AGC) ${ }^{10,22}$ To minimize these issues, the professionals who work in the primary care units carry out training and retraining; the monitored laboratories adopted measures to improve their infrastructure, internal quality control in all stages of the process (sampling, analysis and delivery of the final result), participation in the MEQ and meetings to discuss the discordant cases, contributing to the standardization of cytomorphological criteria, reducing interobserver variability. The UMEQ provided the monitored laboratories with a report with detailed pre and postanalytical evaluation data, CD images of discordant diagnoses, recommendations for improvements that should be implemented, and participated in the continuing education of professionals involved in the process.

Our results showed a good performance of the participating laboratories. However, there is a need to reduce the percentage of rejected samples, discordant results with change of conduct and false-positive results through the systematization of MEQ and continuing education.

One difficulty encountered in the management of MEQ was the lack of reports of experience regarding the way the second outcome was communicated to women with change of behavior, the strategy of calling and selecting the secondary referral units, ensuring reception and counseling. The understanding of the process by these women was fundamental, and not one case of non-acceptance or ethical questioning was registered.

\section{Conclusion}

The implementation of the MEQ has increased the efficiency of the process involved in cytopathological examinations of the cervix and consequently in the screening and early detection of cervical cancer. Our results revealed that this process was an important diagnostic improvement exercise, and its performance in a systematic way had a direct impact on the quality of the cytopathological exams performed by the participating laboratories. The continuing education of professionals, and the continuity of process monitoring were the main strategies that ensured the progressive improvement of the quality and reliability of these exams in the scope of the Unified National Health System (SUS, in the Portuguese acronym), contributing to the qualification of care in the line of care of cervical cancer in the city of Rio de Janeiro. Ethical and responsible behavior throughout the process, especially in the active pursuit of women to change behavior, was critical in the quality of care.

\section{Contributors}

Rocha V. S. O., Malfacini S. S., Gomes A. M. and Rocha C. R. M. declared to have contributed with the conception of the study, collection, and tabulation, critical review, drafting of the manuscript and final approval of the version to be published.
Conflicts of Interest

The authors have no conflicts of interest to declare.

\section{References}

1 World Health Organization. International Agency for Research on Cancer. Globocan 2012: Estimated Cancer Incidence, Mortality and Prevalence Worldwide in 2012. Lyon: IARC; 2017. http://globocan. iarc.fr/. Accessed April 19, 2017

2 Ministry of Health. National Cancer Institute José Alencar Gomes da Silva. [Estimate 2018: Incidence of Cancer in Brazil]. Rio de Janeiro, RJ: INCA; 2018

3 Costa MCE. Situação do Câncer no Brasil e no Rio de Janeiro. Rio de Janeiro, RJ: INCA; 2010. http://bvsms.saude.gov.br/bvs/publicacoes/inca/situacao_do_cancer_no_brasil_e_rio_de_janeiro.pdf. Accessed April 19, 2017

4 Ministry of Health. National Cancer Institute José Alencar Gomes da Silva. [Brazilian Nomenclature for Cervical Cytopathologic Reports]. 3a ed. Rio de Janeiro: INCA; 2012

5 Ministry of Health. National Cancer Institute José Alencar Gomes da Silva. Coordination of Prevention and Surveillance. Division of Early Detection and Network Organization Support. [Brazilian Cervical Cancer Screening Guidelines]. Rio de Janeiro, RJ: INCA; 2016

6 Ministry of Health. National Cancer Institute José Alencar Gomes da Silva. General Coordination of Strategic Actions. Division of Support to the Oncology Attention Network. [Breast Cancer Control Information System (SISMAMA) e Information System for Cervical Cancer Control (SISCOLO): Management Manual]. Rio de Janeiro, RJ: INCA; 2011

7 Bortolon PC, Silva MAF, Corrêa FM, et al. [Quality evaluation of cervical cytopathology laboratories in Brazil]. Rev Bras Cancerol 2012;58:435-444

8 Etlinger D, Pereira SMN, Sakai YI, et al. Análise das discordâncias dos exames citopatológicos do Programa de Monitoramento Externo de Qualidade no estado de São Paulo, Brasil, 20002010. Rev Bras Cancerol 2015;58:481-488

9 Ministry of Health. National Cancer Institute José Alencar Gomes da Silva. [Manual of Quality Management for Cytopathology Laboratories]. Rio de Janeiro, RJ: INCA; 2012

10 Ministry of Health. National Cancer Institute José Alencar Gomes da Silva. [Monitoring Actions to Control Cervical and Breast Cancers]. Rio de Janeiro, RJ: INCA; 2012

11 Ministry of Health. Secretary of Health Care. [Ordinance No. 79, 1998 July 6]. Diário Oficial da União, Brasília, DF, 1998 July 8. http://sna.saude.gov.br/legisla/legisla/prog_prev_canc/SAS_P79_ 98prog_prev_canc.doc. Acessed October 11, 2017

12 Ministry of Health. Secretary of Health Care. [Ordinance No. 92, 2001 October 16]. Diário Oficial da União, Brasília, DF, 2001 October 17. http://sna.saude.gov.br/legisla/legisla/tab_sia/SPS_ SAS_PC92_01tab_sia.doc. Acessed October 11, 2017

13 Ministry of Health. National Cancer Institute José Alencar Gomes da Silva. [National Program for the Control of Cervical and Breast Cancer: presentation]Rev Bras Cancerol 2012;58:317-319

14 Ministry of Health. Ordinance No. 3.388, 2013 December 30. Diário Oficial da União, Brasília, DF, 2013 December 31. http:// bvsms.saude.gov.br/bvs/saudelegis/gm/2013/ prt3388_30_12_2013.html. Acessed October 11, 2017

15 Shirata NK, Pereira SMM, Cavaliere MJ, et al. [Cellularity of the cervicovaginal smear: importance to the quality assurance proceedings in cytopathology]. J Bras Ginecol 1998;108:63-66

16 Landis JR, Koch GG. The measurement of observer agreement for categorical data. Biometrics 1977;33(01):159-174

17 de Freitas HG, Thuler LC. [External quality control for cervical cytology exams performed in the Brazilian Public Health System of Mato Grosso do Sul State]. Rev Bras Ginecol Obstet 2012;34 (08):351-356. Doi: 10.1590/S0100-72032012000800002 
18 Amaral RG, Souza NLA, Tavares SBN, et al. [External quality control of cytological diagnostics in cervical cancer screening: a pilot study]. Rev Bras Anal Clin. 2006;38:79-81

19 [External quality control in cervical cytopathology: an evaluation from 2000-2004]. Rev Saude Publica 2007;41(06):1071. Doi: 10.1590/S0034-89102007000600028

20 Collaço LM, de Noronha L, Pinheiro DL, Bleggi-Torres LF. Quality assurance in cervical screening of a high risk population: a study of 65,753 reviewed cases in Parana Screening Program,
Brazil. Diagn Cytopathol 2005;33(06):441-448. Doi: 10.1002/ dc. 20328

21 Gullo CE, Dami AL, Barbosa AP, et al. Results of a control quality strategy in cervical cytology. Einstein (Sao Paulo) 2012;10(01): 86-91. Doi: 10.1590/S1679-45082012000100018

22 Ázara CZS, Manrique EJC, Tavares SB, Alves de Souza NL, Magalhães JC, Amaral RG. Reproducibility of cervical cytopathology following an intervention by an external quality control laboratory. Diagn Cytopathol 2016;44(04):305-310. Doi: 10.1002/dc.23445 